\title{
FREQUENCY AND ASSOCIATION OF 1691 (G>A) FVL, 20210 (G>A) PT AND 677 (C>T) MTHFR WITH DEEP VEIN THROMBOSIS IN THE POPULATION OF BOSNIA AND HERZEGOVINA
}

\author{
Jusić-Karić $\mathrm{A}^{1, *}$, Terzić $\mathrm{R}^{1}$, Jerkić $\mathrm{Z}^{2}$, Avdić $\mathrm{A}^{1}$, Pođanin $\mathrm{M}^{1}$
}

\begin{abstract}
*Corresponding Author: Amela Jusić-Karić, Ph.D., Faculty of Science and Mathematics, University of Tuzla, Univerzitetska 4, 75000 Tuzla, Bosnia and Herzegovina. Tel: +387-61-289-217. Fax: +387-35-320-861.

E-mail: amela.jusic@untz.ba
\end{abstract}

\begin{abstract}
The $1691(\mathrm{G}>\mathrm{A})$ factor $\mathrm{V}$ Leiden $(\mathrm{FVL})$ and $20210(\mathrm{G}>\mathrm{A})$ prothrombin $(\mathrm{PT})$ mutations are the two most common genetic risk factors in venous thromboembolism. The $677(\mathrm{C}>\mathrm{T})$ methylene tetrahydrofolate reductase (MTHFR) mutation is the most frequently mentioned as an independent genetic risk factor for venous thromboembolism. As there are limited published data on the prevalence of the 1691 , 20210 and 677 mutations in our population, the aim of this study was to determine the frequencies and association of these deep vein thrombosis mutations in the Bosnian population.

This study included 111 thromboembolic patients and 207 healthy subjects with absence of known risk factors for venous thromboembolism. Genotyping of the 1691, 20210 and 677 mutations was done by polymerase chain reaction (PCR), followed by restriction digestion with $M n l \mathrm{I}$, HindIII and HinfI enzymes.

Out of the 111 patients, $18.0 \%$ were heterozygous and $2.70 \%$ were homozygous for the 1691 mutation. Among 207 healthy controls, 3.86\%, were heterozygous for the 1691 mutation. This study confirmed the association of the 1691 mutation with deep vein thrombosis in the Bosnian population odds ratio (OR) [95\% confidence interval $(\mathrm{CI})]=6.0(2.62-14.14) ; p=0.0001)$.

\footnotetext{
${ }^{1}$ Biology Department, Faculty of Science, University of Tuzla, Tuzla, Bosnia and Herzegovina

${ }^{2}$ Clinics for Cardiovascular Disease, University Clinical Centre Tuzla, Tuzla, Bosnia and Herzegovina
}

The 20210 mutation was detected in $2.70 \%$ of patients and it was totally absent in the control group. Allele and genotype frequency of 677 did not differ significantly between the cases and controls $\left(\chi^{2}=1.03 ; p=0.309\right)$.

Keywords: $1691(\mathrm{G}>\mathrm{A})$ factor V Leiden (FVL); $20210(\mathrm{G}>\mathrm{A})$ prothrombin $(\mathrm{PT}) ; 677(\mathrm{C}>\mathrm{T})$ methylene tetrahydrofolate reductase (MTHFR)

\section{INTRODUCTION}

Deep vein thrombosis (DVT) is the most common clinical manifestation of venous thromboembolism with multi factorial pathogenesis. Venous thromboembolism (VTE) occurs as a result of interaction of series of different risk factors including acquired and hereditary conditions. Generally, a tendency toward venous thrombosis can arise from hyperactive anticoagulant pathways, hypoactive anticoagulant mechanisms or hypoactive fibrinolysis [1]. Venous thromboembolism is highly heritable and multiple coinherited genetics risk factors increase the incidence risk [2]. The most common identified mutations interfering with VTE are: $1691(\mathrm{G}>\mathrm{A})$ factor V Leiden (FVL), $20210(\mathrm{G}>\mathrm{A})$ prothrombin (PT), deficiency of protein $\mathrm{C}$, protein $\mathrm{S}$ and antithrombin III.

Blood coagulation factor $\mathrm{V}$ is coded by a gene located on the long arm of chromosome 1 (1q23) and consists of 25 exons and 24 introns [3]. Transition in exon 10 of gene F5 causes a substitution (R506Q) known as factor $\mathrm{V}$ Leiden that has been recognized as the most prevalent genetic risk factor for VTE. Heterozygotes and homozygotes of the 1691 mutation are as- 
sociated with a 7 - and 80 -fold increased risk of venous thrombosis, respectively [4]. It has been estimated that the prevalence of 1691 mutation in the patients with DVT varies between 20.0 and 30.0\% [5]. Estimated frequencies of 1691 mutation among Caucasians range from 2.0 to $9.5 \%$, moderate prevalence is observed in Hispanic Americans and Indians (1.0-5.0\%), whereas it is rare in Asians and Africans ( $<1.0 \%)[6,7]$.

A G to A transition at position 20210 within the 3' untranslated region (3'UTR) of the prothrombin gene has been identified as a risk factor for thrombosis [8]. This substitution in the $P T$ gene results in an increased gene expression that could lead into increasing activity of prothrombin in plasma. Geographic difference in the frequency of the $20210 \mathrm{mu}-$ tation exists in healthy individuals, with the highest frequencies observed in Europe and the Middle East [9], whereas its prevalence among Asians and Africans is $<1.0 \%$ [4]. According to the literature, the relative risk of thrombosis is twice times higher in patients with the 20210 mutation, three times higher in patients with the 1691 mutation and six times higher in patients who have of both mutations.

The $\mathrm{C}$ to $\mathrm{T}$ transition at position 677 in exon 4 of the methylene tetrahydrofolate reductase (MTHFR) gene is recognized as a mutation that interferes with cysteine metabolism and leads to increased levels of plasma homo-cysteine in homozygotes carrying the 677 mutation. The 677 mutation is common in the general population and has been recognized as the risk factor for cardiovascular diseases [10]. The prevalence of 677 ranges 30.0 to $50.0 \%$ (heterozygotes) and 9.0 to $12.0 \%$ (homozygotes) in the general population. The exact impact of the 677 mutation on the occurrence of venous thrombosis has been unclear so far, but it is obvious that the presence of hyperhomocysteinemia increases the risk for thrombosis [11].

Although 1691, 20210 and 677 mutations have been recognized as the most common risk factor for VTE, there are only a few reports of prevalence of these mutations in the healthy Bosnian population $[12,13]$. Our study was conducted in order to investigate the frequency of these mutations and their association with DVT in the Bosnian population.

\section{MATERIALS AND METHODS}

Subjects. Our study included 111 patients with DVT (52 males, 59 females). The median age of pa- tients was 53 years (ranging from 21 to 84). Two hundred and seven healthy individuals were included in the control group (102 males, 105 females), their median age was 45 years (ranging from 18 to 84), without a history of known risk factors for DVT. The samples were collected at the Clinics for Cardiovascular Diseases at the University Clinical Centre Tuzla, Tuzla, Bosnia and Herzegovina. Our investigation was carried out in the Laboratory of Molecular Medicine at the Clinic for Laboratory Diagnostics, University Clinical Centre Tuzla. All cases and controls were fully informed about the study protocol by the main investigator and agreed to participate in the study by signing the written consent form. The study was approved by the Ethics Committee of the University Clinica Centre Tuzla (decision reference numbers 01/1-37-4-25/11 and 01/3-37-25/11).

Methods. The DNA was isolated from EDTA anti-coagulated whole blood (Vacutainer Becton Dickinson, Meylan Cedex, France) using the commercial FlexiGene DNA Isolaton Kit (250) (Qiagen GmbH, Hilden, Ger- many). The 1691, 20210 and 677 mutations were genotyped by polymerase chain reaction-restriction fragment length polymorphism (PCR-RFLP) techniques that were in accordance with previously described protocols $[8,14,15]$. The genotypes were determined by electrophoresis in 4.0\% agarose gel (Sigma Aldrich Chemie $\mathrm{GmbH}$, Münich, Germany) stained with ethidium bromide (Sigma Aldrich).

Statistical Analyses. Statistical analyses were performed by using MedCalc 12.4.0.0 (MedCalc Software, Ostend, Belgium). Deviation of allele and genotype distribution from the Hardy-Weinberg equilibrium was assessed by the $\chi^{2}$ test. For all mutations, the odds ratio (OR) and their $95 \%$ confidence intervals (CI) were calculated according to McHugh [16] to estimate the risk for DVT. Statistical significance was set at a $p$ value of $<0.05$.

\section{RESULTS}

In this study, we investigated the frequency of the most common prothrombotic factors and their association with DVT in patients with DVT and healthy controls in Bosnia and Herzegovina. The frequencies of allele and genotypes of 1691, 20210 and 677 mutations are summarized in Table 1. Of the three tested mutations, only the 1691 mutation was 
shown to be significantly associated with DVT with an $\mathrm{OR}(95 \% \mathrm{CI})=6.0(2.62-14.14) ; p=0.0001$. No association between DVT and the 20210 and 677 mutations was found.
Table 2 shows the allele and genotypes frequencies of the 1691, 20210 and 677 mutations according to gender. Allele and genotype frequencies of the 1691 mutation did not differ significantly between genders

Table 1. Allele and genotype frequencies of the $1691(\mathrm{G}>\mathrm{A})$ FVL, $20210(\mathrm{G}>\mathrm{A})$ PT and $677(\mathrm{C}>\mathrm{T})$ MTHFR mutations.

\begin{tabular}{|c|c|c|c|c|c|}
\hline Mutations & Alleles & $\begin{array}{l}\text { Cases } \\
n(\%)\end{array}$ & $\begin{array}{c}\text { Controls } \\
n(\%)\end{array}$ & $\begin{array}{c}\text { OR } \\
(95 \% \text { CI })^{a}\end{array}$ & $p$ Value \\
\hline \multirow{2}{*}{$1691(\mathrm{G}>\mathrm{A}) \mathrm{FVL}$} & $\begin{array}{l}\text { wild type } \mathrm{G} / \mathrm{G} \\
\text { heterozygous } \mathrm{G} / \mathrm{A} \\
\text { homozygous } \mathrm{A} / \mathrm{A}\end{array}$ & $\begin{array}{c}88(79.30) \\
20(18.00) \\
3(2.70) \\
\end{array}$ & $\begin{array}{c}199(96.14) \\
8(3.86) \\
0(0.0) \\
\end{array}$ & $6.0(2.62-14.4)$ & 0.0001 \\
\hline & $\begin{array}{l}\text { allele } \mathrm{G} \\
\text { allele A }\end{array}$ & $\begin{array}{r}196(89.50) \\
23(10.50)\end{array}$ & $\begin{array}{c}406(98.06) \\
8(1.94)\end{array}$ & $5.6(2.4-12.7)$ & 0.0001 \\
\hline \multirow{2}{*}{$20210(\mathrm{G}>\mathrm{A}) \mathrm{PT}$} & $\begin{array}{l}\text { wild type } \mathrm{G} / \mathrm{G} \\
\text { heterozygous } \mathrm{G} / \mathrm{A} \\
\text { homozygous } \mathrm{A} / \mathrm{A}\end{array}$ & $\begin{array}{c}108(97.30) \\
3(2.70) \\
0(0.00) \\
\end{array}$ & $\begin{array}{c}207(100.00) \\
0(0.00) \\
0(0.00) \\
\end{array}$ & $13.5(0.6-263.9)$ & 0.087 \\
\hline & $\begin{array}{l}\text { allele G } \\
\text { allele A }\end{array}$ & $\begin{array}{c}219(98.64) \\
3(1.36)\end{array}$ & $\begin{array}{c}414(100.00) \\
0(0.00)\end{array}$ & $13.5(0.6-263.9)$ & 0.087 \\
\hline \multirow{2}{*}{$677(\mathrm{C}>\mathrm{T}) \mathrm{MTHFR}$} & $\begin{array}{l}\text { wild type } \mathrm{C} / \mathrm{C} \\
\text { heterozygous } \mathrm{C} / \mathrm{T} \\
\text { homozygous } \mathrm{T} / \mathrm{T}\end{array}$ & $\begin{array}{l}43(38.74) \\
47(42.34) \\
21(18.92) \\
\end{array}$ & $\begin{array}{l}91(43.96) \\
92(44.44) \\
24(11.60) \\
\end{array}$ & $1.24(0.77-1.98)$ & 0.368 \\
\hline & $\begin{array}{l}\text { allele C } \\
\text { allele T }\end{array}$ & $\begin{array}{r}133(66.16) \\
68(33.84)\end{array}$ & $\begin{array}{l}274(70.26) \\
116(29.74)\end{array}$ & $0.82(0.57-1.19)$ & 0.309 \\
\hline
\end{tabular}

FVL: factor V Leiden; PT: prothrombin; MTHFR: methylene tetrahydrofolate reductase; OR: odds ratio; 95\% CI: 95\% confidence interval.

${ }^{a}$ For wild-type $v s$. heterozygous + homozygous.

Table 2. Allele and genotype frequencies of factor $1691(\mathrm{G}>\mathrm{A})$ FVL, $20210(\mathrm{G}>\mathrm{A})$ PT and $677(\mathrm{C}>\mathrm{T})$ MTHFR mutations according to gender.

\begin{tabular}{|c|c|c|c|c|c|c|c|c|c|}
\hline \multirow[t]{2}{*}{ Mutations } & \multirow[t]{2}{*}{ Alleles } & \multicolumn{4}{|c|}{ Patients } & \multicolumn{4}{|c|}{ Controls } \\
\hline & & $\begin{array}{c}\text { Men } \\
n(\%)\end{array}$ & $\begin{array}{c}\text { Women } \\
n(\%)\end{array}$ & $\begin{array}{c}\chi^{2} \\
(d f=1)^{a}\end{array}$ & $p$ Value & $\begin{array}{c}\text { Men } \\
n(\%)\end{array}$ & $\begin{array}{c}\text { Women } \\
n(\%)\end{array}$ & $\begin{array}{c}\chi^{2} \\
(\mathrm{df}=1)^{\mathrm{a}}\end{array}$ & $p$ Value \\
\hline \multirow[t]{2}{*}{$1691(\mathrm{G}>\mathrm{A}) \mathrm{FVL}$} & $\begin{array}{l}\text { wild type } \mathrm{G} / \mathrm{G} \\
\text { heterozygous } \mathrm{G} / \mathrm{A} \\
\text { homozygous } \mathrm{A} / \mathrm{A}\end{array}$ & $\begin{array}{c}38(73.08) \\
13(25.00) \\
1(1.92)\end{array}$ & $\begin{array}{c}46(77.96) \\
11(18.64) \\
2(3.40)\end{array}$ & 0.359 & 0.549 & $\begin{array}{c}97(95.10) \\
5(4.90) \\
0(0.00)\end{array}$ & $\begin{array}{c}102(97.14) \\
3(2.86) \\
0(0.00)\end{array}$ & 0.582 & 0.445 \\
\hline & $\begin{array}{l}\text { allele G } \\
\text { allele A }\end{array}$ & $\begin{array}{l}89(86.40) \\
14(13.60)\end{array}$ & $\begin{array}{r}103(88.80) \\
13(12.20)\end{array}$ & 0.287 & 0.592 & $\begin{array}{c}199(97.54) \\
5(2.45)\end{array}$ & $\begin{array}{c}226(98.26) \\
4(1.74)\end{array}$ & 0.771 & 0.387 \\
\hline \multirow[t]{2}{*}{$20210(\mathrm{G}>\mathrm{A}) \mathrm{PT}$} & $\begin{array}{l}\text { wild type } \mathrm{G} / \mathrm{G} \\
\text { heterozygous } \mathrm{G} / \mathrm{A} \\
\text { homozygous } \mathrm{A} / \mathrm{A}\end{array}$ & $\begin{array}{c}51(98.07) \\
1(1.93) \\
0(0.00)\end{array}$ & $\begin{array}{c}57(96.32) \\
2(3.38) \\
0(0.00)\end{array}$ & 0.226 & 0.634 & $\begin{array}{c}102(100.00) \\
0(0.00) \\
0(0.00)\end{array}$ & $\begin{array}{c}105(100.00) \\
0(0.00) \\
0(0.00)\end{array}$ & - & - \\
\hline & $\begin{array}{l}\text { allele G } \\
\text { allele A }\end{array}$ & $\begin{array}{c}103(99.03) \\
1(0.97)\end{array}$ & $\begin{array}{c}116(98.30) \\
2(1.70)\end{array}$ & 0.223 & 0.636 & $\begin{array}{c}204(100.00) \\
0(0.00)\end{array}$ & $\begin{array}{c}210(100.00) \\
0(0.00)\end{array}$ & - & - \\
\hline \multirow[t]{2}{*}{$677(\mathrm{C}>\mathrm{T}) \mathrm{MTHFR}$} & $\begin{array}{l}\text { wild type } \mathrm{C} / \mathrm{C} \\
\text { heterozygous } \mathrm{C} / \mathrm{T} \\
\text { homozygous } \mathrm{T} / \mathrm{T}\end{array}$ & $\begin{array}{c}18(34.61) \\
25(48.08) \\
9(17.31)\end{array}$ & $\begin{array}{l}25(42.37) \\
22(37.39) \\
12(20.34)\end{array}$ & 0.701 & 0.402 & $\begin{array}{l}42(41.18) \\
49(48.04) \\
11(10.78)\end{array}$ & $\begin{array}{l}49(46.67) \\
43(41.90) \\
12(11.43)\end{array}$ & 0.873 & 0.350 \\
\hline & $\begin{array}{l}\text { allele C } \\
\text { allele T }\end{array}$ & $\begin{array}{l}61(64.21) \\
34(34.79)\end{array}$ & $\begin{array}{l}72(67.92) \\
34(32.08)\end{array}$ & 0.165 & 0.680 & $\begin{array}{r}133(68.91) \\
60(31.09)\end{array}$ & $\begin{array}{c}141(71.94) \\
55(28.06)\end{array}$ & 0.428 & 0.512 \\
\hline
\end{tabular}

FVL: factor V Leiden; PT: prothrombin; MTHFR: methylene tetrahydrofolate reductase.

${ }^{a}$ For wild-type $v s$. heterozygous + homozygous. 
Table 3. The Frequencies of combined genotypes of $1691(\mathrm{G}>\mathrm{A})$ FVL, $20210(\mathrm{G}>\mathrm{A}) \mathrm{PT}$ and $677(\mathrm{C}>\mathrm{T})$ MTHFR.

\begin{tabular}{|c|c|c|}
\hline Combined Genotypes & Patients $n(\%)$ & Controls $n(\%)$ \\
\hline $\begin{array}{l}1691(\mathrm{G}>\mathrm{A}) \text { FVL }(\mathrm{GG}) \text { and } 20210(\mathrm{G}>\mathrm{A}) \text { PT }(\mathrm{GG}) \\
1691(\mathrm{G}>\mathrm{A}) \text { FVL }(\mathrm{GA}) \text { and } 20210(\mathrm{G}>\mathrm{A}) \text { PT }(\mathrm{GA})\end{array}$ & $\begin{array}{l}85(98.84) \\
1(1.16)\end{array}$ & $\begin{array}{c}199(100.00) \\
0(0.00)\end{array}$ \\
\hline $\begin{array}{l}1691(\mathrm{G}>\mathrm{A}) \text { FVL }(\mathrm{GG}) \text { and } 677(\mathrm{C}>\mathrm{T}) \operatorname{MTHFR}(\mathrm{CC}) \\
1691(\mathrm{G}>\mathrm{A}) \text { FVL }(\mathrm{GA}) \text { and } 677(\mathrm{C}>\mathrm{T}) \text { MTHFR }(\mathrm{CT}) \\
1691(\mathrm{G}>\mathrm{A}) \text { FVL }(\mathrm{GA}) \text { and } 677(\mathrm{C}>\mathrm{T}) \operatorname{MTHFR}(\mathrm{TT})\end{array}$ & $\begin{array}{c}34(72.34) \\
7(14.90) \\
3(6.39)\end{array}$ & $\begin{array}{l}90(92.78) \\
6(6.19) \\
1(1.03)\end{array}$ \\
\hline $\begin{array}{l}1691(\mathrm{G}>\mathrm{A}) \mathrm{FVL}(\mathrm{AA}) \text { and } 677(\mathrm{C}>\mathrm{T}) \operatorname{MTHFR}(\mathrm{CT}) \\
1691(\mathrm{G}>\mathrm{A}) \mathrm{FVL}(\mathrm{AA}) \text { and } 677(\mathrm{C}>\mathrm{T}) \operatorname{MTHFR}(\mathrm{TT})\end{array}$ & $\begin{array}{l}2(4.25) \\
1(2.12)\end{array}$ & $\begin{array}{l}0(0.00) \\
0(0.00)\end{array}$ \\
\hline $\begin{array}{l}20210(\mathrm{G}>\mathrm{A}) \text { PT }(\mathrm{GG}) \text { and } 677(\mathrm{C}>\mathrm{T}) \operatorname{MTHFR}(\mathrm{CC}) \\
20210(\mathrm{G}>\mathrm{A}) \text { PT }(\mathrm{GA}) \text { and } 677(\mathrm{C}>\mathrm{T}) \text { MTHFR }(\mathrm{CT}) \\
20210(\mathrm{G}>\mathrm{A}) \text { PT }(\mathrm{GA}) \text { and } 677(\mathrm{C}>\mathrm{T}) \operatorname{MTHFR}(\mathrm{TT})\end{array}$ & $\begin{array}{l}43(97.72) \\
1(2.28) \\
0(0.00)\end{array}$ & $\begin{array}{l}91(100.00) \\
0(0.00) \\
0(0.00)\end{array}$ \\
\hline
\end{tabular}

FVL: factor V Leiden; PT: prothrombin; MTHFR: methylene tetrahydrofolate reductase.

in compared groups $\left(\chi^{2}=0.359 ; p=0.549\right)$, but we found a statistically significant difference of its frequency between women with DVT and women of the control group $\left(\chi^{2}=12.45 ; p=0.001\right)$, and men with DVT and the control group $\left(\chi^{2}=11.42 ; p=0.001\right)$.

The frequencies of combined genotypes of the 1691, 20210 and 677 mutations are presented in Table 3 . Two individuals $(1.16 \%)$ with combined heterozygous genotypes of 1691 and 20210 were part of the patients' group. The highest frequency $(14.89 \%)$ of combined genotypes was detected for compound heterozygotes for 1691 and 677 mutations in the patients' group. This combination of genotypes was observed in $6.19 \%$ controls. In the patients' group we observed $6.39 \%$ individuals who were heterozygous for 1691 (GA) and homozygous (TT) for 677. Based on that, we did not identify any homozygote (AA) for 1691 in the control group, while its combination with the other two mutations was absent.

\section{DISCUSSION}

The observed prevalence of the 1691mutation in this study corresponds to the reported prevalence in the healthy Caucasian population $[2,17-20]$. The relationship between the 1691 mutation and VTE is commonly recognized [21]. According to the data, about $18.0 \%$ of patients with first occurrence of DVT and about $40.0 \%$ of thrombophilic families carry 1691 [5,14]. In this study, the 1691 mutation was shown to be significantly associated with DVT with an OR $(95 \% \mathrm{CI})=6.0(2.62-14.14) ; p=0.0001$. The current observations are consistent with other reports from other countries in the region [22-24].
The second genetic risk factor for vein thrombosis, the 20210 mutation, was present in the Caucasian population with a frequency of 0.7 to $4.0 \%$, with an average close to $2.0 \%$. The prevalence of this mutation was higher in the Southern European countries than in Northern countries, in spite of presence of overlapping between north and south. The 20210 mutation was found to be very rare or even absent in Asian and African populations and American Indians and Australian Aborigines [25]. The greatest frequency of 20210 is reported in Hispanics and Mexican Mestizos. The prevalence of this mutation in patients with VTE was $8.0 \%$ and an even higher prevalence $(18.0 \%)$ was found in selected families with thrombosis. In our investigated group, three out of 111 patients were heterozygotes for the 20210 mutation. In the control group, the 20210 mutation was absent. Our results are in contrast with the results of Adler et al. [13], who observed a frequency of the 20210 mutation in $6.0 \%$ out of 100 healthy individuals from Bosnia and Herzegovina. Discrepancy in results from our study and the study of Adler et al. [13], could be explained by the small number of subjects in the subgroups and inadequate female-to-male ratio in the latter study. This ratio is not sufficient for generalization of the data on the whole Bosnian population, due to the small sample size and limited power of the study. Absence of the 20210 mutation in our control group can also partly explain its lower frequency in the patients.

Two common polymorphisms of the MTHFR gene, 677 and $1298(\mathrm{~A}>\mathrm{C})$, appear to be related to early coronary disease but their relationship with VTE is conflicting [26,27]. Many studies have shown that individuals who have both polymorphic alleles have 
moderately increased concentration of homocysteine. In reference [28] is reported that hyperhomocysteinemia is a weak risk factor for VTE. The prevalence of the $T$ allele varies among races and ethnic groups. In our study, allele and genotype frequencies of the 677 mutation did not differ significantly between healthy subjects and patients with DVT. These results are consistent with the data of Alfirevic et al. [2], Adler et al. [13], Tsai et al. [29] and Beyan and Beyan [30].

Researching the distribution of the 1691, 20210 and 677 mutations according to gender is especially important in women because they undergo hemostatic changes during the pregnancy. We did not observe the difference in the frequencies of these mutations between men and women in the patients' group or in the control group. However, we found statistically significant difference in distribution of the $1691 \mathrm{mu}-$ tation between women with DVT and women in the control group and between men in compared groups. We can only speculate that men and women who were heterozygotes or homozygotes for the 1691 mutation were more prone to develop DVT. Literature data have shown that the combined effect of more than one genetic variant can double or triple the risk for VTE. The combination of the most frequent genetics risk factor, 1691 and 20210, has been frequently found in patients with VTE. The prevalence of $0.4 \%$ of both mutations in individuals with VTE was observed by Ridker et al. [6]. The high frequency of 1691 and $20210(3.0 \%)$ was demonstrated in Croatian patients with DVT [22]. Similar results about coexisting heterozygous forms of 1691 and 20210 were reported by Ehrenforth et al. [31] (11.0\%), Zoller et al. [32] (10.0\%) and Ferraresi et al. [33] (14.0\%). Observed frequency of those two mutations in our study was $1.16 \%$ in the patients' group. The presence of both the 1691 and 20210 mutations increased the risk of recurrent DVT by a factor of 2.6 and the risk of a spontaneous recurrence by a factor of 3.7, as compared with the risk in patients who were heterozygous for the 1691 mutation alone [34]. In contrast to the study by De Stefano et al. [34], we did not confirm a relationship between compound heterozygosity of 1691 and 20210 with DVT, which might be due to a relatively small size of our study population. Our study results indicated that the 1691 and 677 mutations tend to coexist in a heterozygous form in $14.90 \%$ of patients. In large meta-analysis study [35], it was demonstrated that there was no interaction of the 677 variant with 1691 and with 20210 in risk of developing VTE, confirming the hypothesis that 677 is not a risk factor for VTE.

\section{CONCLUSIONS}

The frequency of the 1691, 20210 and 677 mutations in the healthy population in Bosnia and Herzegovina is similar to previously reported prevalence of these mutations in other populations in the region. Based on our results, we can conclude that only the 1691 mutation was significantly associated with DVT in our population. We did not confirm association of other two studied mutations, 20210 and 677, with DVT in the investigated sample of the Bosnian population. The observed frequency of combined heterozygosity for the 1691 and 677 mutations in our study and their possible impact on developing DVT imply that further studies on a larger number of patients from all of Bosnia and Herzegovina are needed for confirmation of our findings.

Declaration of Interest. The authors report no conflicts of interest. The authors alone are responsible for the content and writing of this article.

\section{REFERENCES}

1. Miletich JP, Prescott SM, White R, Majerus PW, Bovill EG. Inherited predisposition to thrombosis. Cell. 1993; 72(4): 477-480.

2. Alfirevic Z, Simundic AM, Nikolac N, Sobocan $\mathrm{N}$, Alfirevic I, Stefanovic M, et al. Frequency of factor II G20210A, factor V Leiden, MTHFR C677T and PAI-1 5G/4G polymorphism in patients with venous thromboembolism: Croatian case control study. Biochemia Medica. 2010; 20(2): 229-235.

3. Segers K, Dahlback B, Gerry AFN. Coagulation factor $\mathrm{V}$ and thrombophilia: Background and mechanisms. Thromb Haemost. 2007; 98(3): 530-542.

4. Katcharin A, Napaporn A, Timaluck S, Pantep A. Prevalence of factor V Leiden (G1691A) and prothrombin gene mutation (G20210A) among different ethnic group in Thai hospitals. J Hematol Transfus Med. 2012; 22(2): 115-120.

5. Rosendaal FR, Koster T, Vandenbroucke JP, Reitsma PH. High risk of thrombosis in patients ho- 
mozygous for factor $\mathrm{V}$ Leiden (activated protein C). Blood. 1995; 85(6): 1504-1508.

6. Ridker PM, Miletich JP, Hennekens CH, Buring JE. Ethnic distribution of factor V Leiden in 4047 men and women. Implications for venous thromboembolism screening. JAMA. 1997; 277(16): 1305-1307.

7. Herrmann FH, Koesling M, Schrŏder W, Altman R, Jiménez Bonilla R, Lopaciuk $\mathrm{S}$, et al. Prevalence of factor $\mathrm{V}$ Leiden mutation in various population. Genet Epidemiol. 1997; 14(4): 403-411.

8. Poort SR, Rosendaal FR, Reitsma PH, Bertina RM. A common genetic variation in the 3'-untranslated region of the prothrombin gene is associated with elevated plasma prothrombin levels and an increase in venous thrombosis. Blood. 1996; 88(10): 3698-3703.

9. Bavikatty N, Kileen A, Akel N, Normolle D, Schmaier A. Association of the prothrombin G20210A mutation with factor V Leiden in a midwestern American population. Am J Clin Pathol. 2000; 114(2): 272-275.

10. Tosetto A, Missiaglia E, Frezzato M, Rodeghiero F. The VITA project: C677T mutation in the methylene-tetrahydofolate reductase gene and risk of venous throm-boembolism. Br J Haematol. 1997; 97(4): 804-806.

11. den Heijer M, Lewington S, Clarke R. Homocysteine, MTHFR and risk of venous thrombosis. N Engl J Med. 2005; 3(2): 292-299.

12. Karic A, Terzic R, Jerkic Z, Mustedanagic-Mujanovic J. The frequency of C677T methylentetrahidrofolate reductase (MTHFR) polymorphism in Southern East Bosnian population. J Biomet Biostat. 2013; 4(4): 1-4.

13. Adler G, Agnieszka G, Valjevac A, Czerska E, Kiseljaković E, Salkic N. Prevalence of genetic prothrombotic risk factors: $1691 \mathrm{G}>\mathrm{A} \mathrm{FV}$, 20210G $>$ A PT and 677 C $>$ T MTHFR mutations in Bosnian population. Ann Hum Biol. 2014; 42(6): 576-580.

14. Bertina RM, Koelman BP, Koster T, Rosendaal FR, Dirven RJ, de Ronde $\mathrm{H}$, et al. Mutation in blood coagulation facto $\mathrm{V}$ associated with resistance to activated protein C. Nature. 1996; 369(6475): 64-67.
15. Froost $P$, Blom HJ, Milos R, Gazette $P$, Sheppard $\mathrm{CA}$, Matthews RG, et al. A candidate genetic risk factor for vascular disease: A common mutation in methylene-tetrahydrofolatereductase. Nat Genet. 1995; 10(1): 111-113.

16. McHugh M. The odds ratio: Calculation, usage and inerpretation. Biochemia Medica. 2009; 19(2): 120-126.

17. Kejzer M, den Hajer M, Blom HJ, Bos GMJ, Willems HPJ, Gerrits WBJ, et al. Interaction between hyperhomocysteinemia, mutated methylenetetrahydro-folate reductase (MTHFR) and inherited thrombophilic factors in recurrent venous thrombosis. Thromb Haemost. 2002; 88(5): 72-78.

18. Meglic L, Stegnar M, Milanez T, Bozic M, Peterlin B, Peternel $\mathrm{P}$, et al. Factor V Leiden, prothrombin $20210 \mathrm{G}>\mathrm{A}$, methylenetetrahydrofolate reductase $677 \mathrm{C}>\mathrm{T}$ and plasminogen activator inhibitor $4 \mathrm{G} / 5 \mathrm{G}$ polymorphism in women with pregnancy related venous thromboembolism. Eur J Obstet Gynecol Reprod Biol. 2003; 111(2): 157-163.

19. Berge E, Haug KB, Sandset EC, Haughbro KK, Turkovic M, Sandset PM. The factor V Leiden, prothrombin gene 20210GA, methylenetetrahydrofolate reductase $677 \mathrm{CT}$ and platelet glycoprotein IIIa $1565 \mathrm{TC}$ mutations in patients with acute ishemic stroke and atrial fibrillation. Stroke. 2007; 38(3): 106-171.

20. Pauer H, Voigt-Tschirschwitz T, Hinney B, Burfeind P, Wolf C, Emons G, et al. Analyzes of three common thrombophilic gene mutations in German women with recurrent abortions. Acta Obstet Gynecol Scand. 2003; 82(10): 942-947.

21. Koster T, Roosendal FR, de Ronde H, Riet E, Vandenbroucke JP, Bertina R. Venous thrombosis due to poor anticoagulant response to activated protein C: Leiden thrombophilila study. Lancet. 1993; 342(8886-8887): 1503-1506.

22. Coen D, Zadro R, Honović, Banfic Lj, RukavinaStavljenic A. Prevalence and association of the factor V Leiden and prothrombin G20210A in healthy subjects and patients with venous thromboembolism. Croat Med J. 2001; 42(4): 488-492.

23. Đorđevic V, Rakicevic Lj, Mikovic D, Kovac M, Miljic P, Radojkovic D, et al. Prevalence of factor V Leiden, factor V Cambridge, factor 
II G20210A and meth-ylenetetrahydrofolatereductase C677T mutations in healthy and thrombophilic Serbian populations. Acta Haematol. 2004; 112(4): 227-229.

24. Arsov T, Miladinova D, Spiroski M. Factor V Leiden is associated with higher risk deep venous thrombosis of large blood vessels. Croat Med J. 2006; 47(3): 433-439.

25. Jadaon MM. Epidemiology of prothrombin G20210A mutation in the Mediterranean region. Mediterr J Hematol Infect Dis. 2011; 3(1): e2011054. doi: 10.4084/ MJHID.2011.054.

26. Isotalo PA, Donnely JG. Prevalence of methylene-tetrahydrofolatereductase mutations in patients with venous thrombosis. Mol Diagn. 2000; 5(1): 59-66.

27. Moglinicka-Nizankowska E, Adamek L, Grzanka P, Domagala TB, Sanak M, Krzanowski M, et al. Genetic polymorphisms associated with acute pulmonary embolism and deep venous thrombosis. Eur Respir J. 2003; 21(1): 25-30.

28. D'Angelo A, Beltramentti C. Venous disease. In: Carmel R, Jacobsen DW, Eds. Homocysteine in Health and Disease. Cambridge, Cambridgeshire, UK: Cambridge University Press. 2001:401-414.

29. Tsai AW, Cushman M, Tsai MY, Heckbert SR, Rosamond WD, Aleksic N, et al. Serum homocysteine, thermolabile variant of methylenetetrahydrofolat reductase (MTHFR) and venous thromboembolism: Longitudinal investigation of thromboembolism etiology (LITE). Am J Hematol. 2003; 72(3): 192-200.

30. Beyan C, Beyan E. MTHFR 677 CT gene polymorphism is not a risk factor for venous throm- boembolism. Çukurova Med J. 2014; 39(1): 189-190.

31. Ehrenforth S, von Fepka-Prondsinski M, Aygoren-Pursun E, Nowak-Gottl U, Scharrer I, Ganser A. Study of the prothrombin gene 20210GA variant in FV:Q506 car-riers in the relationship to the presence or absence of juvenile venous thromboemolism. Arterioscler Thromb Vasc Biol. 1999; 19(2): 276-280.

32. Zoller B, Svanson PJ, He X, Dahlback B. Identification of the same factor $\mathrm{V}$ gene mutation in 47 out of 50 thrombosis-prone families with inherited resistance to activated protein C. J Clin Invest. 1994; 94(6): 2521-2524.

33. Ferraresi P, Marchetti G, Legnani C, Cavallari E, Castoldi E, Mascoli F, et al. The heterozygous $20210 \mathrm{G} / \mathrm{A}$ prothrombin genotype is associated with early venous thrombosis in inherited thrombophilia and is not increased in frequency of artery disease. Arterioscler Thromb Vasc Biol. 1997; 17(11): 2418-2422.

34. De Stefano V, Martinelli I, Mannuccio P, Paciaroni K, Chiusolo P, Casorelli I, et al. The risk of recurrent deep venous thrombosis among heterozygous carriers of both factor $\mathrm{V}$ Leiden and the G20210A prothrombin mutation. N Engl J Med. 1999; 341(11): 801-806.

35. Simone B, De Stefano V, Leoncini E, Zacho, Martinelli I, Emmerich J, et al. Risk of venous thromboembolism associated with single and combined effects of factor V Leiden, prothrombin 20210A and methylenetetra-hydrofolate reductase C677T: A meta-analysis involving over 11,000 cases and 21,000 controls. Eur J Epidemiol. 2013; 28(8): 621-647. 
